\title{
Simone Weil: uma voz feminina que desafiou o século $\mathrm{XX}$
}

Simone Weil: a female voice that challenged the $20^{\text {th }}$ century

\author{
ANDREIA CRISTINA SERRATO (iDa
}

\section{Resumo}

Este artigo trata de Simone Weil e sua percepção da condição humana no mundo do trabalho. Filósofa, professora, operária, camponesa, escritora e militante, é na sua práxis que se compreende algumas reflexões que realizou sobre os regimes totalitários da sua época. Evidencia a mística de Simone Weil como experiência para sair dessa condição de escravidão e superação da opressão e da dominação. Esse estudo traz um recorte da vida, obra e luta dessa mulher francesa, que descreve sua experiência de regimes opressores, situando-se lado a lado com os oprimidos e marginalizados da sociedade e, como mulher, reflete, experimenta e denuncia as opressões.

Palavras-chave: Opressão. Dominação. Mística. Experiência. Ato e prática.

\section{Abstract}

This article addresses Simone Weil and her perception of the human condition in the world of work. Philosopher, teacher, worker, peasant, writer, and activist, it is in her praxis that can be understood some of her reflections on the totalitarian regimes of the time. The mysticism of Simone Weil is demonstrated as an experience to get out of this condition of slavery and to overcome oppression and domination. This study highlights the life, work, and struggle of this French woman, who describes her experience of oppressive regimes, standing side by side with

\footnotetext{
* A pesquisa sobre o pensamento da filósofa francesa, Simone Weil, iniciou com a tese doutoral, em 2010, sob o tema Corporeidade e Mística: Experiência, práxis e ética em Simone Weil. Essa reflexão continua sob novos horizontes temáticos. A tese de doutorado encontra-se disponível em: https://www.maxwell.vrac.puc-rio.br/colecao.php?strSecao=resultado\&nrSeq=30412@1

a Pontifícia Universidade Católica do Paraná, Curitiba, Paraná, Brasil. Doutora em Teologia, e-mail: andreia.serrato@pucpr.br
} 
the oppressed and marginalized in society, and as a woman reflects, experiences, and denounces oppression.

Keywords: Oppression. Domination. Mysticism. Action and practice.

\section{Introdução}

Nascida em 1909, parisiense, no seio de uma família judaica, Simone Adolphine Weil, foi filósofa, professora, militante, operária e dedicada ao tema da condição humana no mundo do trabalho. Revelou precocemente uma inteligência notável, mas compreendia-se inferior à inteligência de seu irmão mais velho, André Weil, que a impulsionou na busca pela verdade. Florence de Lucy afirma que, para Simone Weil, "sua necessidade da verdade é a origem de todas as suas escolhas teóricas e práticas" (WEIL, 1988, p. 11).

Aos 14 anos, Simone teve uma crise porque acreditava que somente aqueles que tivessem mente brilhante encontrariam a verdade - no caso, seu irmão. Ela, então, prefere a morte a não chegar à verdade. Até que, um dia, teve o que chamou de uma experiência de transcendência ${ }^{1}$, afirmando que, de súbito, teve a certeza de que todos que buscam a verdade podem penetrar no reino da verdade, mesmo aqueles de mente medíocre, se desejarem e fizerem um esforço para alcançá-la, assim alcançarão. Isso a tranquilizou e lhe deu paz, e nunca mais se preocupou com isso.

Ainda na adolescência, participou de uma greve dos trabalhadores, em que reivindicou como se fosse um deles. Interessava-se pela política², e quando um de seus amigos se diz comunista ela afirma ser bolchevista - e isso não eram apenas palavras no ar. Apesar de conhecer pouca coisa acerca do bolchevismo, ela o reconhecia "nos grupos que reivindicavam as camadas desprezadas pela hierarquia social” (PÉTREMENT, 1973, p. 40).

\footnotetext{
${ }^{1}$ Um dia, olhando pela janela, contemplando as montanhas, sentia muito a pureza ao olhar os picos nevados e teve o que ela considera sua primeira experiência transcendental. Foi tomada por uma enorme consolação em seu coração: “Após meses de trevas interiores, tive de súbito e para sempre a certeza de que, não importa qual seja o ser humano, mesmo que suas faculdades naturais sejam quase nulas, pode penetrar neste reino da verdade, reservada ao gênio, se somente deseja a verdade e faz perpetuamente um esforço de atenção para alcançá-la. Torna-se também um gênio, mesmo pela falta de talento" (WEIL, 1952, p. 34).

2 Para saber mais: FORNI ROSA, G. Simone Weil: política e mística.
} 
Estudou filosofia, foi professora, operária, camponesa, escritora, militante. Devido à ocupação nazista, Simone Weil saiu da França e foi para Nova York e depois para Londres. Trabalhava em demasia e costumava recusar a alimentação prescrita pelos médicos, o que a debilitou cada vez mais. Morreu sozinha, em agosto de 1943, aos 34 anos, em Ashford, Inglaterra. Era uma forma de protesto contra as condições em que eram mantidos os prisioneiros de guerra na França, o seu povo.

Este estudo versará sobre a vida e o pensamento de Simone Weil atrelados à sua práxis; para ela; filosofia é ação, apresentando as condições do trabalho e algumas reflexões que realizou sobre os regimes totalitários da sua época. Em seguida, traz a sua mística como experiência para sair da condição de escravidão e superação da opressão e da dominação.

Aqui será apresentado apenas um recorte da vida, obra e luta dessa mulher francesa, que não faz nenhuma reflexão sobre o feminismo, como sua contemporânea Simone de Beauvoir, contudo escreve e experimenta condições de regimes totalitários, opressores, em que a mulher está lado a lado com os oprimidos e marginalizados da sociedade e, como mulher, reflete, experimenta e denuncia as opressões.

\section{Simone Weil: da filosofia à ação — uma biografia}

Desde cedo, Simone Weil se compadecia com a dor do outro, o que a fez ser solidária e agir em prol daqueles que sofriam. Ela tinha uma saúde frágil em contraposição à sua força avassaladora de amar e se compadecer pelos que sofriam ou eram marginalizados. Experimentou quase tudo o que escreveu. Para conhecer mais a jovem francesa, é importante perceber como entendia a filosofia: "coisa exclusivamente em ato e prática" (WEIL, 1950, p. 335). Ou, ainda, filosofia como conhecimento prático e "exercício espiritual", (WEIL, 1994).

Para Simone, o intelectual tinha que estar "na vida". Foi, talvez, uma das pensadoras de sua época, se não a única, que articulou tão bem e de forma tão coerente, vida e filosofia, pois escreve aquilo que vive e exige esta mesma lógica daqueles que escrevem. Qualquer teoria é o trabalho humano e, portanto, uma forma de ação que transforma um dado - Simone Weil iria pensar que no próprio ser humano se estabelece uma relação em que a prática afeta a teoria, uma vez que atua sobre o primeiro. É no contexto de uma teoria abrangente que une os dois, 
contrastando dialética da ação e da teoria. Para ela, é inadmissível ficar como espectadora, não lhe convém. Toda conduta de Simone procede de uma lógica do pensamento que se encontra na lógica da ação (WEIL, 1988, p. 16).

Sendo assim, a articulação para compreender o pensamento da autora deve ser acompanhada "de uma exploração dos elementos históricos e dos respectivos contextos onde esses mesmos conceitos têm seu ambiente de constituição" (VALLE, 2019, p. 582), pois nela se dá sempre "uma clara sintonia entre a experiência e a escrita, entre pensamento e ação ou entre vida e obra" (PERES, 2009, p.78). Em 1931, aos 21 anos, tornou-se professora, numa escola secundária para moças em Le Puy. Nessa cidade, ingressou no movimento sindical, organizando uma greve geral que paralisou toda a cidade. Isso aconteceu depois de dizer para algumas alunas que "a família é prostituição legalizada e a esposa é uma amante reduzida à escravidão", quando foi então transferida de escola e mudou-se de cidade. Como mulher à frente de seu tempo, compreendeu, refletiu e soltou sua voz sobre a condição que as mulheres, em algumas situações familiares, viviam e era aceitável pela sociedade da época. Denunciou o que as mulheres, na maioria, já internalizavam como normalidade.

Em suas férias de verão, em 1932, viajou para a Alemanha, onde presenciou a situação política do país. Foi uma das primeiras pessoas a denunciar a barbárie que tomou conta de toda a Alemanha com o crescimento do movimento nazista, assim como a passividade dos sociais-democratas e o silêncio dos comunistas stalinistas. Ambos deixavam o campo aberto para o avanço de Hitler e do nacional-socialismo. Notou a subordinação, seja da social-democracia à burguesia gestora do Estado capitalista, seja da Internacional comunista à burocracia gestora do Estado soviético.

Da mesma maneira que criticou o colonialismo e o capitalismo, criticava o comunismo e a ideia de revolução. Suas reservas com o comunismo recebem duras críticas por parte dos membros franceses do partido. Simone não permitiu que isso a afetasse e seguiu atentamente os acontecimentos que se desenvolveram na Alemanha (PÉTREMENT, 1973, p. 218-220).

Em Roanne, outubro de 1933 (DEVAUX; LUSSY, 1989, p. 329), a professora francesa segue participando dos movimentos políticos. Mas agora sente compaixão particular pelas prostitutas e quer conhecer seu contexto e toda sua miséria. Entende que se experimentar a miséria humana desde dentro e compreendê-la lhe 
dará meios para superá-la. Seus amigos dão testemunho de que Simone ansiava acompanhar todos nas alegrias e nas tristezas (PÉTREMENT, 1973, p. 273).

Nesse mesmo ano publicou um artigo considerado herético pelos marxistas ortodoxos “Allons-nous vers la révolution prolétarienne?" (Vamos para a revolução proletária?), no qual enfatizou que a opressão do proletariado era causada pelas técnicas da produção industrial presentes tanto no capitalismo quanto no socialismo burocrático vigente na Rússia. Aos materialistas históricos faltara a capacidade de enxergar o real com a lucidez que lhes permitisse tanto compreender a realidade histórica das primeiras décadas do século XX, quanto formular a crítica à infundada expectativa de uma efetiva ou iminente revolução proletária.

Não se pode deixar de mencionar seu encontro com Trotski ${ }^{3}$. Antes do encontro, o revolucionário bolchevista reagiu diante do artigo publicado, em que ela manifesta sua postura pessimista sobre o poder de uma classe sobre a outra. Trotsky reagiu com dureza a esse artigo e o tachou de "fórmula de antigo liberalismo revigorado com uma exaltação anarquista barata" (WEIL, 1988, p. 405nota 177; WEIL, 1994, p. 21). Ao ler a crítica, Simone Weil convenceu seus pais a receber Trotsky em sua casa para que pudesse conversar com ele. E assim aconteceu. O diálogo versou sobre a Rússia, se era ou não um estado operário, e foi subindo de tom, até o ponto em que Trotsky gritou em diversas ocasiões. Depois da reunião com seus companheiros, o russo declara aos pais de Simone que eles poderiam dizer que ali se constituiu a Quarta Internacional (PÉTREMENT, 1973, p. 280; WEIL, 1994, p. 21). Simone, mulher jovem, em torno de seus 20 anos, com coragem e a ousadia de quem conhece a realidade e se sensibiliza por ela, discute no mesmo tom com um homem, líder político, que a desqualificou em sua reflexão.

Neste ponto, apresenta-se a reflexão da historiadora e teóloga americana Elizabeth S. Fiorenza. Ela afirma que é necessário traçar uma mudança cultural em geral, criando novos modelos paradigmáticos para interpretar a realidade, passando de um modelo androcêntrico para um modelo interpretativo feminista, a fim de transformar e construir uma nova realidade (1992, p. 26)4. Mesmo que ainda não seja possível uma mudança tão ampla, alguns passos podem ser dados. A partir

\footnotetext{
${ }^{3}$ Leon Trotsky foi um intelectual marxista e revolucionário bolchevique. Nesta época, era exilado russo.

${ }^{4}$ A teóloga propõe que sejam revistos os modelos teóricos interpretativos da Bíblia; o primeiro ela chama de modelo doutrinal, o segundo, o modelo da exegese histórico positivista, o terceiro é uma hermenêutica dialógica e o último, o da teologia a libertação.
} 
desse pensamento de Fiorenza, compreende-se Simone Weil como uma mulher que refletiu e agiu para a transformação da sociedade a fim de criar uma nova realidade.

Albert Camus afirmou, em 1949, após a Segunda Guerra, que seria impossível imaginar um renascer para a Europa que não levasse em conta as exigências definidas por Weil. Contudo, parece que, como mulher intelectual, ela não ganhou tanta expressividade à época. O que se constata é que ela se adiantou à ação dos padres operários na década de 1980, pois foi às fábricas já na década de 1940. Adiantou-se, ainda, à teologia da libertação, pois compreendeu o cristianismo como a religião que faz o ser humano sair da condição de escravidão — ou seja, os liberta — como afirmou em 1935: "o cristianismo é a religião dos escravos, e eu entre eles" (WEIL, 1952, p. 37). Esse escrito foi uma crítica a Nietsche, pois para ele o cristianismo mantém seu povo na escravidão. Para Weil, ao contrário, não é apatia, é o cristianismo a religião que conduz a sair da condição de escravizado.

\section{Trabalho e poder totalitário}

Em 1934, Simone Weil licenciou-se do magistério, mesma época em que escreveu Réflexions sur les causes de la liberte et de l'oppression sociale (Reflexões sobre as Causas da Liberdade e da Opressão Social). Ela partiu de uma profunda análise da natureza da liberdade individual para explicar como, nos sistemas políticos ou agrupamentos sociais em que se vive, e nos moldes em que os concebe, a liberdade é um paradoxo e a opressão, uma fatalidade. Weil vai da teoria às implicações práticas de tal concepção, revelando as múltiplas formas de opressão e dissecando os seus mecanismos, deitando por terra as esperanças numa resposta revolucionária - refém dos mesmos mecanismos, inerentes à condição humana.

Nesse momento, depara-se com a tirania daqueles que sabem e, dessa forma, compreende que só o uso da razão no gabinete de trabalho não basta para entender, por exemplo, as causas da opressão operária. Decide, por isso mesmo, fazer experiências concretas, para compreender a opressão capitalista no mundo, inserindo-se na vida desses operários, na fábrica. 
No ano de 1935, escreveu uma grande reflexão, La condition ouvrière ( $A$ Condição Operária $)^{5}$, que é a soma dessas observações experientes. Trata-se de seu "Jornal da fábrica", em que relata seus dias duros e pesados de trabalho na fábrica, e uma série de textos em que lança a filosofia e a moral dessa experiência. Nessa reflexão, a jovem francesa relaciona sua época à revolução industrial:

Muitas vezes se fala da revolução industrial para designar exatamente a transformação que se produziu na indústria quando a ciência se voltou para a produção e apareceu a grande indústria. Mas pode-se dizer que houve uma segunda revolução industrial. A primeira se define pela utilização científica da matéria inerte e das forças da natureza. A segunda se define pela utilização científica da matéria viva, isto é, dos homens (WEIL, 1951, p. 182).

Evidencia-se de longe que trabalhar na fábrica, ou ainda entre os camponeses e pescadores, não era uma atitude romântica, a intenção da filósofa era fundamentalmente compreender a relação da técnica moderna, no caso da fábrica, com os aspectos essenciais da civilização (GABELLIERI, 2001, p. 15).

Em dezembro de 1934, Simone vai trabalhar em uma fábrica como manobrista de máquina. Essa experiência a transformou de uma vez por todas. Em uma carta a sua amiga Albertine Thévenon, em 1934, escreveu: "Saí muito diferente do que eu era quando eu entrei - esgotada fisicamente, mas moralmente endurecida" (WEIL, 1951, p. 16).

O calor do forno era quase insuportável, assim, as brutais mudanças de temperaturas eram prejudiciais também. O corpo quase não suportava o peso das peças, as mãos frágeis machucavam ora pelo calor, ora pela rudeza do metal. Relata suas experiências e de seus colegas de trabalho que nas dificuldades "matam"6 as peças a serem executadas (WEIL, 1951, p.16). Há, ainda, a brutalidade do tratamento dos chefes com os empregados, pois a produção nem sempre é suficiente para ganhar para comer (WEIL, 1951, p .32). Simone afirma que a rapidez dos movimentos com que deveriam agir diante das máquinas era maior que o pensamento, "matando-os". Compreende que não havia como esses operários fazerem a revolução, pois não tinham tempo para pensar. Deixa, assim, um insuperável diagnóstico das causas da escravidão moderna: "as coisas representam o papel dos

\footnotetext{
${ }^{5}$ Existem muitos escritos de Simone Weil sobre esta importante experiência, além de seu livro A Condição Operária, o segundo volume das Oeuvres Complètes, 1988.

${ }^{6}$ Matam: expressão que utiliza para falar quando estragam uma peça na usinagem, quando a peça foi perdida e não pode ser aproveitada.
} 
homens, os homens representam o papel das coisas: eis a raiz do mal" (WEIL, 1991, p. 206).

A árdua rotina do trabalho na fábrica e os sentimentos que brotavam como angústia, medo e outros elementos que despersonalizam os seres humanos — desembocam em uma submissão instantânea, em que se perde o sentimento de dignidade pela humilhação recebida, resultando no efeito da escravidão. Assim, o ser humano é reduzido ao estado de coisa, de matéria inerte, torna-se repetidor de movimentos mecânicos inconscientes, se desumanizando (WEIL, 1951, p. 147). Após a dura experiência da fábrica, antes de retornar ao magistério, ela relatou sair com "a alma e o corpo em pedaços" (WEIL, 1952, p. 36). E escreve: "O que sofri ali me marcou muito, [...] Recebi para sempre a marca da escravidão, como a marca de um ferro quente que os romanos colocavam em seus escravos mais desprezíveis. Desde então, passei a ver-me como uma escrava" (WEIL, 1952, p. 36).

Essa foi a experiência do próprio malheur ${ }^{7}$, sofrimento físico, psíquico, espiritual e social, como denominou, que até então não tinha experimentado. E nesse domínio do sofrimento, o malheur é para ela a própria escravidão (WEIL, 1951, p.20). Essa experiência foi muito dura, mas a transformou de uma vez por todas. Não tomar consciência disso "é o trabalho sem luz de eternidade, sem poesia, sem religião" (WEIL, 1994, p. 209). Viver e ter consciência do trabalho executado foi o que, mais tarde chamou de mística do trabalho, na qual se encontram conciliadas todas as aspirações do ser humano, no equilíbrio do carnal e do espiritual (WEIL, 1994, p. 360). Não somente o corpo físico, mas sua dignidade sai afetada.

A minha vida na fábrica, foi uma experiência única. Quanto a mim mesma, veja o que significou o trabalho na fábrica. Mostrou que todos os motivos exteriores (que antes eu julgava interiores) sobre os quais, para mim, se apoiava o sentimento de dignidade, o respeito por mim mesma, em duas ou três semanas ficaram radicalmente arrasados pelo golpe de uma pressão brutal e cotidiana (WEIL, 1952, p. 81-2).

A dolorosa experiência do trabalho fabril em condições de aguda exploração é alimento para reflexões que marcam toda sua trajetória como pensadora. Afirma que: "nenhuma poesia sobre o povo é autêntica se a fadiga não estiver presente

\footnotetext{
${ }^{7}$ Não há uma tradução para essa palavra, utiliza-se no original. Tradução aproximativa poderia ser "desgraça".
} 
nela, assim como a fome e a sede nascidas da fadiga" (WEIL, 1994, p. 202), nos deixam um insuperável diagnóstico das causas da escravidão moderna.

Ela sustenta que o totalitarismo está na origem do materialismo brutal. Descobriu que a opressão não resulta em rebelião, mas em obediência e apatia - e até mesmo na internalização dos valores do opressor. Simone também escreveu ainda "Ne recommençons pas la guerre de Troie" (Não vamos recomeçar a guerra de Tróia!) para a revista Nouveaux Cahiers, lamentando que, "embora vivamos entre realidades mutáveis, diversas e determinadas pelo jogo volúvel de necessidades externas, agimos, lutamos, sacrificamos a nós e a outros em nome de abstrações cristalizadas, isoladas" (como nação, capitalismo, comunismo e fascismo).

Isso porque o trabalhador passou a executar gestos determinados pela necessidade imposta pela máquina (no âmbito da fábrica), sem entender a relação destes com o resultado final de sua ação. Socialmente, o imperativo econômico impôs um ritmo desenfreado à produção e transformou o trabalho numa repetição de gestos sem sentido para o trabalhador, que entrou num ciclo de trabalhar para comer e comer para trabalhar. Aí está, para ela, o caráter destrutivo da opressão: à classe privilegiada cabe a atividade do pensamento e, aos trabalhadores, a ação irrefletida sobre o mundo, e não o pensamento.

A sua própria experiência de operária metalúrgica, levou-a a compreender melhor que, em nenhum país onde prevaleciam as técnicas produtivas implantadas a partir do modo de produção capitalista (incluindo os que estavam sob o domínio do nazismo, do fascismo e do stalinismo), o planejamento da produção estava prestes a cair sob o controle operário; assim, os mais generosos ou corajosos militantes revolucionários, na mais trágica hipótese, seriam mártires em busca de sua própria morte.

Para a pensadora francesa, a dominação que aportou nos diversos locais de colonização e neocolonização, como portadora de "civilidade" e com o evangelho da aculturação (o que seria para ela um desvio no projeto evangelizador) foi desenraizadora e fez grande mal para os povos originários.

O ensinamento maior que Simone Weil fornece não se restringe a uma elaboração redacional de regulamentos para preservação do direito humano ao acesso e preservação da cultura, mas se dá no campo das orientações éticas, do (re)ascender o compromisso com a necessidade dos bens materiais e imateriais 
para todos, para que vigore uma dimensão de alteridade e cuidado com o que é sagrado para (e no) outro.

Simone Weil formula uma exigência que torna o trabalho mais individual, a fim de que ele possa ser mais bem dominado pelo operário cujo pensamento é cortado pelo gesto de seu corpo servindo as máquinas. Ligar espírito e corpo será uma fonte primordial da definição da espiritualidade do trabalho. Mesma fonte, nos parece, foi proposta da ciência no Cahier III: "Ciência e técnica. Pode-se conceber também uma ciência da natureza orientada sobre uma técnica de aperfeiçoamento interior". Para Weil, nas pesquisas científicas, o ser humano deve ser o centro de interesse, caso contrário, a ciência fica obscurecida no tecnicismo (DEVAUX; LUSSY, 2008, p. 356).

Em julho de 1936, com a eclosão da Guerra Civil Espanhola, Simone juntou-se à causa republicana no front de Aragon para lutar, juntamente com os anarquistas, nessa guerra. Mesmo sendo míope e frágil, foi incorporada a uma unidade de anarquistas. Sem nenhum preparo para a vida militar, ela quase que imediatamente enfiou o pé numa panela de óleo fervente e teve de ser resgatada por seus pais, que a mandaram para Assis, na Itália, para recuperar-se. Desanimada com as atrocidades que havia visto seu próprio "lado" cometer, Simone reafirmou seu pacifismo. Em 1939, ela se torna uma camponesa - e mais uma vez come e trabalha como eles. Na experiência no campo, Simone Weil diz que se trata apenas de transformar a vida cotidiana em uma metáfora à significação divina, uma parábola. "Uma metáfora, são palavras sobre as coisas materiais e revestidas de uma significação espiritual”, segundo ela, "o espetáculo do grão que penetra no sulco (na terra), se o camponês que semeia é capaz de ler este espetáculo na alma carnal (o velho homem) que morre para ressuscitar como nova criatura de Deus" (DEVAUX; LUSSY, 2008, p. 265). Durante o tempo do trabalho no campo, refletiu sobre o corpo que se torna alimento para os demais.

Em abril de 1942, emigrou para os Estados Unidos, de onde começa a planejar seu retorno à Europa. Valendo-se dos seus contatos, Simone conseguiu ser chamada a Londres, onde se viu encarregada de analisar todas as sugestões de como organizar a França depois da guerra. Desapontada com o nacionalismo gaullista, que considerou antiquado, logo renunciou ao cargo, e afirmando que não tinha o direito de comer mais do que seus camaradas na França ocupada, deixou-se passar fome até que teve de ser hospitalizada. 
Simone analisa, justamente, um dos aspectos do trabalho que é o desenraizamento como opressão do ser humano, pois este é tirado do seu meio de origem, apartado de seus valores éticos e culturais e lhe são impostos novos meios que não são os seus. Tanto que o trabalho deixa de ter um papel importante na vida de cada pessoa, sendo visto como mera utilidade para produzir cada vez mais, assim nem os operários e nem os camponeses usufruem do que produzem.

Depois de sua recuperação, ela fez um último esforço para compilar suas ideias sobre a tão sonhada "sociedade sem opressão". O resultado encontra-se em seu livro L'enracinement. Prélude à une déclaration des devoirs envers l'être humain, escrito em 1943. Simone reafirma seu posicionamento:

antes que a sociedade possa ser regenerada, devemos reconhecer que cada problema social é um sintoma de um profundo "desenraizamento" (um estado mais ou menos similar à vida puramente vegetativa), produzido por - naturalmente - dinheiro, "mecanismo", ciência e tecnologia, todos eles divorciados da vida e através do uso da força. A política deve ser algo mais do que impor uma ideologia sobre a tática particular de um grupo social que queremos levar adiante. Deveria ser uma reflexão inteligente sobre a realidade, conduzida por pensadores profundos (WEIL, 1949).

A emergência histórica do consumo esteve relacionada a alguns fatores, como, por exemplo, o aumento da produtividade industrial, o avanço tecnológico, a produção em grande escala e não mais artesanal. O produtor não mais se sentia o autor de produtos para as necessidades reais, mas de produtos para serem vendidos. Vender tornou-se a meta final da produção. Os objetos tornaram-se cada vez mais descartáveis (ARENDT, 2010, p. 160). Ao lado dessa reflexão está a desorientação pessoal pela perda dos valores tradicionais, pois não há mais quem herde o sentido moral e emocional que um dia eles materializavam.

Nessa direção, em seus escritos L'enracinement, Simone Weil afirma que o humano tem suas raízes por participar de maneira real na coletividade que conserva a história do passado e projeta um futuro. Por participação natural em seu lugar de nascimento, profissão, ou seja, o meio em que vive. A necessidade de ter raízes é a "necessidade mais importante e mais desconhecida da alma humana" (WEIL, 1949, p. 36). No entanto, o enraizamento pode ser definido como "um meio vital, não tem uma determinação particular, mas a atmosfera necessária para viver este 'plano celeste' que é o ser humano, cujas raízes estão ao mesmo tempo no céu e sobre a terra" (WEIL, 1949, p. 36): Daí a necessidade que tem o ser humano de sinais 
sensíveis de incondicionalidade se enraíza nos tesouros herdados do passado, que devem sem cessar ser “assimilados e recriados por nós” (WEIL, 1949, p. 16).

Por aqui nascem as obrigações absolutas da coletividade ${ }^{8}$, portanto a pretensão exclusiva à existência é a fonte da idolatria totalitária e do desenraizamento. Sem a possibilidade de um enraizamento, o indivíduo estaria exposto ao malheur ${ }^{9}$. A análise crítica de Simone Weil sobre o desenraizamento abarca não somente o trabalho, mas também a relação do ser humano com o tempo, que ela chama de necessidades da alma. Esse desenraizamento seria todos caminhos que levam o ser humano a uma coisificação, como se explicou anteriormente.

Seu desejo de ir à fábrica provavelmente foi para conciliar a organização que exige a sociedade industrial com as condições de trabalho e de vida de um proletariado livre. Essa questão, ainda sem resposta, foi buscar no calor infernal da fábrica próximo do sofrimento dos operários (BINGEMER, 2011, p. 34). Simone Pétrement descreveu a necessidade de sua amiga:

devia pensar que ali, onde reflexão teórica não encontrava solução, o contato com o objeto poderia sugerir uma resposta. O objeto era a miséria para o que tentava encontrar remédio e solução. Submergida ela mesma na miséria, veria melhor que remédios são apropriados para tratá-las. E depois de tudo isso, era necessário conhecer aquilo de que se queria falar (PÉTREMENT, 1973, p. 329).

Após visitar alguns aspectos, encontros e experiências da vida da filósofa, operária, intelectual francesa, consideram-se a seguir aspectos místicos que lhe deram ainda mais voz e encarnação no mundo, na tentativa de superação dos totalitarismos e opressão vigente.

\footnotetext{
${ }^{8} \mathrm{~A}$ família tem grande importância na formação de indivíduos. Nas grandes cidades, tornam-se parte das grandes massas e não são tratados em suas individualidades, tornam-se isolados e perdidos. Mas quando participam de pequenos grupos mantém sua personalidade (CARREL, 2016, p.304).

${ }^{9}$ Esse conceito é central em sua obra: L'Enracinement: prélude à une déclaration des devoirs envers l'être humain. Malheur: para ela a dor seria apenas física, o sofrimento seria tanto físico como psíquico. Já o malheur envolve todas as esferas: física, psíquica e social e, principalmente, a luta por controle - base dos mecanismos de opressão social. "O principal fator da luta por controle é uma disputa pelo poder, enraizada no medo da morte, num tipo de morte que remeteria o indivíduo à morte de sua personalidade" (WEIL, 1949, p. 93).
} 


\section{A mística da descriação e recriação para superar a violência}

Pierre Hadot (1922-2010), filósofo e historiador francês, pesquisou a filosofia grega e constatou que os gregos pensavam a filosofia como modo de vida e não como disciplina acadêmica. Simone Weil filosofou de maneira grega, pois, para conhecer seu pensamento, há que conhecer sua vida (BINGEMER; PUENTE, 2011, p. 10). Simone dirá que precisamos pensar por nós mesmos. E pensar assim nos faz encontrar-nos na presença de nossos semelhantes, porque "não há relação filosófica sem uma transformação essencial na sensibilidade e na prática da vida" (WEIL, 1999, p. 123-124).

Aqui aproximamos o pensamento da autora à teologia feminista que apresenta uma teologia fundamentada mais na bíblia, uma teologia da experiência.

Como já citamos, Elizabeth S. Fiorenza afirma a necessidade de uma mudança cultural de superação do modelo androcêntrico para um modelo interpretativo feminista. Relaciona-se aqui a lógica do pensamento e da ação de Simone Weil como a reflexão apresentada pela teologia feminista, a experiência atrelada à reflexão, o que Simone Weil fez muito bem como fonte de libertação. Mulher operária, camponesa, professora, militante, mística. Todas as experiências e reflexões surgem como fonte de libertação para o povo marginalizado. Uma voz feminina em meio ao poder opressor, androcêntrico, refletido e vivido a partir de sua condição de mulher, um modelo interpretativo feminino para a transformação da realidade.

Um dos pontos de transformação para Simone Weil foi sua experiência mística com o cristianismo. Antes de apresentá-lo, tracemos alguns pontos sobre o que se compreende por mística. "A mística significa no vocabulário cristão uma forma especial de conhecimento de Deus que se caracteriza por sua condição experiencial e por chegar a Deus além do que permite alcançar o conhecimento por conceitos" (VELASCO, 2004, p. 17).

Quando falamos em experiência mística, é importante ressaltar que "somente atendendo a dimensão ética, social e política da existência estará o místico em condições de realizar uma experiência mística autêntica" (VELASCO, 1999, p. 465). Para Velasco, experiência mística consiste na união da própria vontade com a vontade de Deus, ou seja, no amor ao próximo, como meio e expressão do amor de Deus e inclui a dimensão ética, a provoca e a desenvolve: "porém, dada a relação estreita e 
recíproca que mantém estas duas dimensões, é possível mostrar que a experiência ética remete à experiência mística" (VELASCO, 1999, p. 462). É possível mostrar uma experiência ética do crente, e inclusive uma experiência ética de todo ser humano. $A$ ética é um espaço de autotranscendência que nos remete à abertura ao outro, a vida acontece neste espaço ético: “Estive nu e me vestiste [...]” (Mt 25, 36).

A experiência mística descentra a pessoa: ela sai de seu ego e é reestruturada a partir daquilo que tem de mais profundo. Essa experiência mística acontece no corpo de carne, frágil, finito. Esse é o processo que percebemos em Simone Weil, esvazia-se de si e deixa espaço para que Deus nasça no (nela) ser humano.

Para Simone Weil, o movimento de esvaziamento total de si é o momento da espera para encontrar Deus e ser recriada por Ele. Esse esvaziamento, ou o que ela chama de detachement, é criado pelo malheur, pela desgraça que atinge o ser humano. Neste ponto, em seu infinito amor, espera Deus para se des-criar e se recriar nele, imitando a kenosis divina. Assim, Deus mesmo se esvazia de sua condição divina para ensinar ao ser humano esta kenosis, podendo, nesse despojamento total, ser encontrado por Ele, a exemplo de Cristo na cruz. A teoria da kenosis, portanto, baseia Simone Weil sobre o princípio de que o ser humano é dotado de maneira constitutiva de um vazio.

Esse sentimento de abandono no mundo, da ausência de Deus, de desamparo total, abre para a presença da graça que vem resgatar o ser humano. Ao mesmo tempo em que o malheur (desgraça) destrói o ser humano existencialmente, também deixa aberto o ser humano para a presença do amor e da graça de Deus que vem resgatá-lo dessa condição.

Com essa passagem rápida por alguns momentos da vida e reflexão dessa grande autora, uma voz profética do século XX, como afirmou Gabellieri (2017), finaliza-se com seu último projeto, para tentar interromper a guerra que acometia seu povo, uma das suas ideias mais ousadas, o projeto de enfermeiras de primeira linha. Acredita-se que iniciou o projeto Enfermeiras de primeira linha entre 1940 e 1942 (DEVAUX; LUSSY, 2008, p. 401-411) ${ }^{10}$. A ideia que Simone tinha era que ao colocar as mulheres enfermeiras que já trabalhavam na guerra no front de batalha,

\footnotetext{
$10 \mathrm{O}$ texto pode ter sido escrito nos últimos dias que esteve em Marseille ou ainda quando chegou a Nova York. Ela o submeteu à opinião de Joë Bousquet e depois o enviou às pessoas que poderiam facilitar a execução do projeto (Lettre à Joë Bousquet. In: DEVAUX; LUSSY, 2008, p. 444).
} 
de mãos vazias, ninguém teria coragem de atacá-las. Elas desceriam de paraquedas e se posicionariam no front. Ela acreditava que, assim, a guerra seria interrompida. A ideia era levar o projeto para o Ministério da Guerra. Ela o redige em inglês e envia ao presidente Roosevelt. Ele leu o projeto. Contudo, parece que ninguém acreditou que daria certo e nem arriscaria tal fato. Concorda-se que que foi uma tentativa bastante ousada, que poderia interromper a violência. Mas, claro, seria um risco muito grande colocar as mulheres no meio da guerra, uma completa loucura.

Pode-se traçar aqui, inclusive, uma relação com as Mães da Praça de Maio, na Argentina. Mães que saíram às ruas, durante a ditadura militar Argentina, entre 1976 a 1983, para denunciar o assassinato e desaparecimento de seus filhos. Carregavam apenas seus lenços brancos na cabeça simbolizando o tecido das fraldas de seus filhos. Essas mulheres batiam de porta em porta para receber notícias dos filhos desaparecidos. Foram ao Ministério do Interior, a quartéis e destacamentos de polícia, escreveram aos integrantes da Junta Militar e não obtiveram respostas. Elas marchavam em solidariedade para protestar contra as atrocidades cometidas pelo regime militar. Até hoje são símbolo de resistência e reúnem-se na praça em frente à Casa Rosada, sede do Governo do Estado. Elas foram o primeiro grupo a se organizar contra as violações de direitos humanos. Essas mulheres criaram uma força dinâmica e inesperada, que existia em oposição às restrições tradicionais às mulheres na Argentina e em toda a América Latina. Mulheres que foram consideradas pelo poder como subversivas, algumas torturadas e assassinadas.

Completa loucura frente ao poder totalitário vigente. Essa experiência das Mães da Praça de Maio é, tal qual a de Simone Weil, que apresentamos ao longo deste texto, a radicalidade na configuração ao outro e a força que as moveu para reivindicar contra o poder opressor. A radicalidade desse engajamento está à altura do projeto revolucionário que entende portar. O pensamento da ação se desenvolve sobre dois planos distintos: este do estudo das condições do trabalho, pois eles estão sob condições de exploração, e o das condições da possibilidade de uma transformação radical da sociedade. Nesses domínios nada está garantido, tudo merece atenção. Para Janiaud, Simone Weil tem pouca preocupação de distinguir seu militarismo do de seus colegas, e continua filósofa, preocupando-se ainda em transformar a sociedade e não as condições de trabalho. Mas seu pensamento vai evoluindo, ao ganhar familiaridade com as condições materiais e perspectivas do mundo operário (JANIAUD, 2002, p. 31). 


\section{Considerações finais}

Simone Weil denunciou e experimentou situações talvez inimagináveis para uma mulher de sua época e dentro da lógica patriarcal imperante, ainda difícil para as mulheres na atual sociedade, principalmente em países latino-americanos, como o Brasil. Recorda-se que ela acreditava que somente mentes brilhantes, como a de seu irmão, um homem, chegariam à verdade. Apresentou-se como uma mulher "inimiga de toda forma de totalitarismo", e profundamente crítica de toda idolatria, apontando a tragédia que seria o desenraizamento humano em diversas instâncias, principalmente a cultural, religiosa e a do trabalho.

Para, Simone "o ser humano ocupa um lugar central e é considerado em um contexto ontológico-relacional” (MARIANELLI, 2009, p. 121-122). Assim, sua filosofia da ação compreende o esvaziamento de si, respondendo ao chamado e apelo do Amor, esse amor compreendido a partir do Cristo. Simone Weil, bem como outras mulheres - para citar algumas, Hannah Arendt, Edith Stein, Simone de Beauvoir, as Mães da Praça de Maio -,ensinam que é preciso estar sempre presente e jamais se desesperar, que a mulheres podem e devem agir na sociedade, chegar à dimensão do político e fazer ouvir uma outra voz que não a da nua violência, do patriarcado vigente, mas a voz daquelas que clamam por justiça. Mais. Pode-se avançar muito além da voz, concretizando o que rompe a cadeia da violência, dos totalitarismos, das injustiças e poder.

Assim, estudar a filósofa francesa é divulgar a possibilidade do rompimento com poderes totalitários que submetem o ser humano à condição de "massa de manobra", ou ainda objeto do poder capitalista. Essa mulher de saúde frágil articulou muito bem a militância, a reflexão e a práxis em sua força na lógica do pensamento que recupera profecia, mística e a dignidade das pessoas. Uma figura que está na interface da práxis à intelectualidade, da mística à solidariedade.

\section{Referências}

ARENDT, H. A condição humana. 11. ed. Rio de Janeiro: Forense Universitária, 2010.

BINGEMER, M. C.; PUENTE, F. R. Simone Weil e a filosofia. São Paulo, Loyola; Rio de Janeiro, PUC-Rio, 2011. 
BINGEMER, M. C. Simone Weil: una mística en los limites. Buenos Aires: Ciudad Nueva, 2011. CARREL, A. O homem esse desconhecido. São Paulo: Edipro, 2016.

DEVAUX, A.; LUSSY, F. Simone Weil. In: Oeuvres complètes, v. 1. Tomo VI. Cahiers I (1933septembre 1941). Paris: Gallimard, 1994.

DEVAUX, A.; LUSSY, F. Simone Weil. In: Oeuvres Complètes. Tomo I: Premiers écrits philosophiques. Paris: Gallimard, 1988.

DEVAUX, A. ; LUSSY, F. Simone Weil. In : Oeuvres Complètes IV-1: Écrits de Marseille (19401942), Philosophie, Science, Religion, Questions politiques et sociales. Paris: Gallimard, 2008.

DEVAUX, A. ; LUSSY, F. Simone Weil. In : Oeuvres complètes. Écrits historiques et politiques. Vers la guerre (1937-1940). Paris: Gallimard, 1989.

FIORENZA, E. S. As origens cristãs a partir da mulher - Uma nova hermenêutica. São Paulo: Paulinas, 1992.

GABELLIERI, E. Simone Weil. Paris: Ed. Ellipses, 2001.

GABELLIERI, E. Penser le travail avec Simone Weil. Bruyères-le-Châtel: Nouvelle Cité, 2017.

JANIAUD, J. Simone Weil: I'attention et l'action. Paris: Presses Universitaires de France, 2002.

MARIANELLI, M. O humanismo cristão de Simone Weil. Concilium, v. 4, n. 332, p. 121-139, 2009.

PÉTREMENT, S. La vie de Simone Weil. Paris: Fayard, 1973. 2.v.

SERRATO, A.; SOUZA, W. Práxis Místico-Ética em Simone Weil: a Compaixão pelo Outro sentida à flor da pele. Pistis \& Praxis - Teologia Pastoral, Curitiba, v. 10, n. 2, p. 308-337, maio/ago. 2018.

VALLE, B. Simone Weil: o sofrimento como pathos da Filosofia. Aurora, Curitiba, v. 31, n. 53, p. 574-603, 2019.

VELASCO, J. M. El fenômeno místico: estúdio comparado. Madri: Trotta, 1999.

VELASCO, J. M. La experiencia mística. Estudio interdisciplinar. Madri: Trotta, 2004.

WEIL, S. L'enracinement. Prélude à une déclaration des devoirs envers l'être humain. Abingdon-on-Thames: Routledge, 1949.

WEIL, S. La condition ouvrière. Paris: Gallimard, 1951.

WEIL, S. Attente de Dieu. Paris: La Colombe, 1952.

WEIL, S. Écrits historiques et politiques II. Paris: Gallimard, 1991. 
WEIL, S. La gravedad y la gracia. Madrid: Trota, 1994.

WEIL, S. La notion de valeur. In: WEIL, S. Oeuvres. Paris, Gallimard, 1999.

WEIL, S. Perspectives. Allons-nous vers la révolution prolétarienne? In: DEVAUX, André A.; LUSSY, Florence de. Oeuvres Complètes II-1. Paris: Gallimard, 1988. 